\title{
Searching for cultural, historical, ethical and philosophical roots of sport in archaic and classical Greek philosophy
}

\author{
Peter Sagat - Marian Ambrozy
}

DOI: 10.18355/XL.2022.15.01.09

\begin{abstract}
Already the Homeric period meant a high social status for successful athletes. However, it was exclusive; it excluded those whose time was needed to work for a living. Democratization in Athens and the militarization of sport in other fields had brought the spread of sport to the wider classes. Xenophanes became the first critic of the sport as a philosopher. Sophists, in turn, emphasized the importance of educational training for life, including sports education. Although the character of the historical Socrates is problematic, it is generally believed that Socrates left behind the legend of a physically immensely disposed, resilient man. Plato consolidated the role of sport through his role in social philosophy. Specifically, he spoke of the importance of the virtue $\alpha v \delta \rho \varepsilon i ́ \alpha$. Although Aristotle characterizes kalokagathia and defined the role of sport within virtues, he was critical in its evaluation. He refused to practice sports if it led to a deterioration of the body. Partly archaic, especially classical Greek philosophy provided a theoretical rationale for recognizing sport as a meaningful activity, but also its critique.
\end{abstract}

Key words: ancient sport, poleis, sports games, Plato, Aristotle

\section{Introduction}

"The philosophy of sports is a relatively young philosophical discipline. It attracts increasing attention of philosophers from different countries" (Stolyarov, 2017: 202). Its foundations were laid in the archaic and classical period of Greek philosophy. In ancient Greece (in its poleis) a form of sports competition (Greek ayov). Sports flourished with the gathering of many people - spectators. The Olympic Games, which started in $776 \mathrm{~B}$. C., were only one of the forms of ayov. In addition to the Olympic Games, there were Pythian Games, Isthmian Games and Nemean Games. In the first centuries, these sports games were mostly competitions among the privileged classes, and only later active did participation spread widely. As is well known, their winners belonged to the most respected contemporaries, and the preserved memoirs remember them with due respect even after their death.

The aim of the study is to try to find the roots of the relationship of the citizens of Greek communities to sports. We do this by examining the links of a social, historical, philosophical, ethical and religious nature. We strive for the most comprehensive grasp of the original perception of sport through the prism of philosophy. We formally follow the line of history of ancient thought, but we strive for a multidisciplinary approach to interpretation. The range of problems grasped goes from the oldest Greek thinkers to Aristotle. We have sought to include in our study all the relevant philosophical authors of the archaic and classical periods of ancient Greek thought.

\section{Historical elaboration of the topics}

Anyone who wants to understand the original ancient values, must reflect on Homer's Iliad and Odyssey. This poet created an image of a man equal to the ancient ideal embodied in the ancient Greek gods. In the mentioned works, Homer also touches on sports games, namely the Phaiacian games (Odyssey Book 8), Patroclos games (Iliad Book 23) and Penelope games (Odyssey Book 22 and 23) - compare (Dombrowski, 2012). In Homer's world, "all sport activities are ludus, but it is paidia, the unregulated and unprepared form of bodily energy that brings the player into play" 
(Dombrowski, 2015: 107). The Iliad shows us interesting facts about determining the winners of the games. It was still not exclusively the sporting results that were making the decisions.

"Victors are often determined by the sponsor's view of the seniority, status, and honor of contestants, and often regardless of the actual placement in the contest itself" (Scanlon, 2018: 6). It is quite important what social environment the athletes who appear in the epic poems come from. Epeius is a skilled carpenter who built the Trojan Horse, but his social status is not equal to that of other warriors, as ancient society had a relatively deep respect for crafts. Homer mentions a boxing competition. Epeius is in the Iliad a comic figure. Games in Phaeacia host competitions in running, wrestling, jumping, discus, and boxing. Episodes in Iliad and Odyssey pointing to sports competition show that not everyone is handy in everything, regardless of his or her social status. The role model was Odysseus, although considered a soldier in Troy, "in the palace of the Alcinoos the same hero is admired as a living statue - a piece of art" (Zuchora, 1983: 7). Probably there competitions, where it was possible to compete with each other even in a clearly different social position, as is the case here with Homer.

"The aristoi, as the wealthiest part of archaic Greek society, were the holders of a specific ideology which was connected with sport, as well as other parts of this society" (Wyskok, Bronikowska, 2018: 1477). On the other hand, in the mentioned period, kakoi were creating a type of inhabitants who had to work in agriculture in order to make a living. Homer's implement in reflection of sporting events is important for example in the history of medicine, as there is the first literary record of head trauma in European culture (Konsolaki, et al., 2010). Advances in sports and medicine were closely interconnected."Whereas war encouraged the development of surgical knowledge springing out of medical experience on the battlefield, peace promoted the burgeoning of sport as an integral part of Greek upbringing, allowing the channeling of young people's aggressiveness into physical competition“" (Appelboom, Rouffin, Fierens, 1988: 594).

At some point in archaic Greek society, tyranny arose in some ethnic Greek citystates. This relatively widespread form of government in some city-states preceded democratic establishment. Some tyrants tried to legitimize their government through sport (in the form of anagon). If the military operations caused increase of the importance and possession of kakoi, the aristoi sought to underline their importance through their lifestyle without work, as physical work was despised by ancient man. This "idle" life style was also reflected by participation in Olympic Games. Homer's lines testify it: "You should come forward, too, as our guest, And try your hand at one of the sports, if you are skilled in any. I'm sure you are, because there is no greater glory a man can win in life, than the glory he wins with his hands and feet " (Homer, Odyssey 110).

This required high physical fitness and the ability to fight. "From the seventh century $\mathrm{BC}$ onward, the main aims of physical fitness were pleasure, the desire for fame and the manifestation of one's high social status" (Wyskok, Bronikowska, 2018: 1481). Within the poleis, the role of sport in education can best be pointed out in archaic Greek society in the Athenian paideia and in the Spartan agoge. In both cases, the sport played an extremely important role. Panhellenic Games were an excellent opportunity to promote one's own physical readiness for combat. More evidence of the seriousness of this event within the Hellenic world was also the conflict between

XLinguae, Volume 15 Issue 1, January 2022, ISSN 1337-8384, eISSN 2453-711X 
Elis and Pisa. Interestingly, Homer claimed that sports games took place also outside the Greek world. He mentions their cultural roots in Egypt.

In the case of the Miletians, of whom only a few credibly true accounts have been preserved, we cannot speak of a reflection on sport. Pythagoras and pythagoreans devoted themselves to mathematics, religion and the recognition of $\dot{\alpha} \kappa о v \sigma \mu \alpha \tau \alpha$, but they are not known to have any influence on sport. Later pythagoreans said that a healthy soul resides in a healthy body, but did not directly affect the development of the sport. The Pythagorean win expectancy model is only named after Pythagoras, it really has nothing to do directly with him (Kaplan, Rich, 2017). Regarding Pythagoras, it can be recalled that Pythagorean followers were also Milon and Iccus, both Olympic victors (Zhmud, 2012). Heraclitus and Parmenides, soaked in the metaphysical theme, did not comment on the problem.

Eleat's inspirator, the poet Xenophanes, known for his philosophical sense of humor, left us at least a very critical testimony about the Olympics. Xenophanes first literally describes the glory of the winners of these games: "Nay, should a man win victory by the swiftness of his feet, or in the five-contest [pentathlon], there where the precinct of Zeus stands, by the streams of the river of Pisa [i.e., Alpheus] in Olympia; or else in wrestling, or by possessing skill in the painful boxing, or again in that dreadful contest which they call pankration: he would be more glorious [sc. than others] to look upon, in the eyes of his fellow-citizens; and he would win the privilege of a conspicuous first-seat at the contests; he also would have bread from the public stores, granted to him by the city; and even a present to serve him as his heirloom" (Xenophanes, DK B2).

But that's not all. In other parts of the fraction he says that such a winner is less worthy of rewards than him, Xenophanes, who in theology of naturalis pointed out the falsity of traditional Hellenistic religion. Prioritizing force over useful art (wisdom) is unjustified, he thinks. A man good at boxing or wrestling, even if he won the five contests, would not gain for his hometown better government, nor it would fill the supplies in the polis chambers. "Xenophanes' rebellious attack on the traditionally highly esteemed Olympionikai" (Marcovich, 1978, p. 18) was very atypical and violating habits at the time, but for the themes and style of Xenophanes, who used to break many established conventions and values, it was a significant statement. After all, he is even more critical, saying that they deserve lower rewards than a good educator. It is a kind of philosophical justification for the ceiling in the rewards of Olympic winners that Solon (Milne, 1943) introduced as part of the reforms. Popper seeks to rehabilitate Xenophanes as the founder of the Greek enlightement (van Nispen, 2020).

Although the later democratic establishment in Athens opened the way for sport to the broad masses, it did not have an immediate effect on sports participation. Sport was associated with the military. The Athenian demos organized sports competitions, in which they invested a lot of money. Athenian athletes continued to be influenced by the elite, although a number of new sporting events took place in Athens during the first half century of democracy. "In antiquity the complaint was occasionally made that the Athenians actually spent more on staging festivals than on fighting wars (e.g. Dem. 4.35-7; Plut. Mor. 349a)" (Pritchard, 2016: 53). According to most experts, this complaint was exaggerated. In fact, more attention was paid to war and its costs.

"The figure of the athlete dominates the whole of ancient philosophy" (Scala 2016: 541). Athletes also escaped the sarcasm of comedies, which testifies to their seriousness. Demos did not question the athletes. Let's not forget that during the 
democratic government in Athens, the winners of the Panhellenic games received not only free meals, but also honorary places in the leading sports games (Pritchard, 2012). Such winners gained social recognition equal to the general of the victorious wars. The middle classes, much less the poorer classes, generally did not have education for sports, as child labor was needed for families in these sections of society. The sporting event was to some extent similar to a war - it had pre-agreed rules. Let us not forget that once the war was more like a sport, as it was conducted through regulated conventions (Cornell, 2002). Violation of customs was perceived as impiety and reduced the value of military victory (Pritchard 2016: 63).

Later there was a mass shift in the number of fighters, e.g. the Athenian navy introduced a military salary. The later increase in the number of fighting men also meant the expansion of sport to several sections of society through exercises. "When hoplites (heavy infantry soldiers) became more and more important in battles, they achieved more civil rights than before, at the same time, the sport games became the most regular form of military training" (Daquing, 2010: 6807). The militarization of sport was thus behind its more massive expansion, along with political changes. Let us not forget the religious dimension of ayov, for example Olympia was the center of worship of Zeus. The lower classes could also take part in athletic competitions. Sometimes even women were winning the Olympics. The historical record preserved the event according to which during Domitian's reign in the late 1st $\mathrm{c}$ a woman, Flavia Thalassia, won the $200 \mathrm{~m}$ run. It is evidence that a woman could also compete in the Hellenistic period. Anyway, the victory of the woman from Ephesus was a curiosity at that time (Reid, 2020a). Let us not forget that the history of the Athenian polis was filled with an almost constant struggle.

Athletics is known to be a widely promoted in another important Greek polis, Sparta. Scanlon believes that negative phenomena such as pederasty have been linked to it (Scanlon, 2005). Information on sports life in Sparta can be obtained from Xenophon's Lakedaimonion Politeia. Of interest is the dedication of athletics to unmarried women. "Spartan system placed a great deal of emphasis on order and that athletics played a key role in maintaining social order at Sparta" (Christesen, 2012: 246). In Sparta, sport meant part of a more complex social structure, "sports in Sparta were part of a highly organized educational and social system" (Christesen, 2017: 544).

Sophists also contributed to the demand for education, including in physical education. "A contrast between sophist and Socratic ideas from Athens of the 5thcentury $\mathrm{BC}$ is used to demonstrate the contribution of a sound philosophical foundation can make in professional practice" (Corlett, 1996: 84). However, let us recall that this contrast is mainly from Plato's point of view. Modern views on sophists seek to abstract from Plato's view and they appreciate sophists more as a beneficial source for culture. Protagoras piece "On Wrestling" is not about sports, but about „intellectual matches“. Protagoras was not a sports coach, but a top sophist. However, the sophists still had something in common with sports. Sophists were traveling teachers who taught mainly in sports gymnasiums. The performances of sophists were a present part of many sports games. Hippias himself says that in this sense he is a regular participant in the Olympic Games. He himself seems to be the author of the list of Olympic winners. Argumentation competitions in which sophists took part had a structural resemblance to sports competitions, they had spectators, etc. Protagoras was a frequent participant and performer in such competitions. Plato also reflects the great respect he aroused in the dialogue of the same name; as Protagoras

XLinguae, Volume 15 Issue 1, January 2022, ISSN 1337-8384, eISSN 2453-711X 
leads two-thirds of the dialogue in argumentative form over Socrate. Diogenes Laertios claims that Protagoras even organized such competitions.

Plato's traditional view of Socrates portrays him, among other things, as an extremely physically resilient man who does not mind lodging, cold, or adverse weather conditions (Thompson, 2002). According to many researchers, Socrate's authentic legacy was just some small Socratic schools, such as the Kynics. Socrates' literature often had a therapeutic function (Suvák, 2014), which dominated the role of preserving historical reports about Socrates. The kynical school, in reference to Socrates, preferred self-sufficiency, unpretentiousness and physical resilience. Xenophones kept an important testimony of Socrates, according to which he spoke about caring for the body to be strong and healthy. Socrates also sees Xenophon's Path to virtue as an exercise (Xen., II.6.39). According to him, exercise, training and coaching are necessary for all beautiful human qualities. Physical condition from his point of view, does not arise on its own, but it can be significantly increased by exercise, even in those who are weak. He considers the difficulties of a physically well-prepared person to be much less than the difficulties of a physically unprepared person. He especially appreciates qualities such as endurance and toughness. Exercise of the body is applicable in self-control, better performance in mental activity, acquiring good habits, strengthening the will (Wollner, 2010).

Plato's theory of education in the middle and late period can be understood relatively consistently. We abstract from some internal controversies, for example from the contradictions between 523b-524d and 537e-539d in Book VII of Plato's Republic, pointed out by Heckel (2017). Plato in Republic paid great attention to the exercise in preparation for the guard class. The silver generation had to be physically fit in his conception - apart from mental virtues. He considered various exercises suitable for the propagation of this generation. The virtue of the silver generation is courage ( $\alpha \delta \rho \rho i ́ \alpha)$. According to the Timaeus dialogue, this basic virtue is placed between the diaphragm and the neck, the corresponding organ being the heart. This somatic placement of the second of the localized virtues is important. From time immemorial, the heart has been considered the seat of courage, and some thinkers have also considered it the seat of the soul (for example, the idea of stoics). A well-known physician, a prominent surgeon Galenos (130 - 200) considered the heart to be the seat of bravery. His dependence on Plato is obvious.

“In Plato's Republic, sport serves the educational objectives of personal virtue, intellectual achievement, and political harmony. But to understand and perhaps apply Plato's insight today, we must revisit our conceptual dichotomies of mind versus body, academics versus athletics, and individual versus community" (Reid 2007: 160).

Plato looked at the state holistically, considering man to be the most important part of his mind. The role of practice in the silver (and of course the highest gold) generation at Plato is very important. Children of the silver and gold generations (this does not apply to the iron generation that lives in families) are brought up by the state, among other things, by training in gymnastics. Men and women train in joint education. However, practicing naked did not mean any free love, as sexual union was to be regulated by the state. Plato reminded that one should play as much as possible (Oborný, 2011). He definitely meant sports games in particular. At Plato, play was one of the central activities of educational activity. "Children learned best in playful activities that attracted their enthusiasms, that "turned the eye of their souls to the Good and True" (Hunnicutt, 1990: 211). The sports game can also be subsumed under this. It is known that he himself was considered a skilled athlete, the name Plato was 
not his birth name, but he obtained it for his broad athletic figure from his gymnastics teacher. The silver and gold generations, like the higher strata of society, were to be educated in the field of gymnastics, which enhanced the body and spirit and allowed further intellectual progress of the individual, potentially to the status of rulers philosophers. As Reid points out, for Plato, the basic leitmotif of gymnastics is body cultivation, military skills, and physical beauty, not moral education. "The beautiful athletic body is framed in ancient Greek thought, not just as an aesthetically pleasing image, but as an ideal expression of a certain kind of soul" (Reid 2012: 281).

The acquired qualities lead to the improvement of the soul. "Plato offers a highly distinctive account of the value of physical education in terms of its vital contribution to the development of a part of the soul that he characterizes in terms of 'spirit', 'energy' and / or 'initiative'" (Carr, 2010: 3). Plato first of all emphasized the concern for soul, and its quality is the main goal. Good physical preparation is at best a means on the path to moral virtues. If we are to believe in Plato's early dialogue, he largely takes these views from Socrates. Dambrowski is convinced that Plato "did have a wide-ranging set of beliefs concerning athletics (and sport) in almost all of its dimensions and that he did not denigrate sport" (Dombrowski 1979: 29). Along with education in gymnastics, Plato considered early education to be important in mathematics, which is a conditio sine qua non for moral education. Jenkins (2015) argues that the specificity of Plato's moral education requires knowledge of the Forms, which is achieved through mathematical education. This increases the intellectual capacity of young people, necessary for a full-fledged moral.

Plato sometimes uses the analogy of sport in argumentation in his dialogues. In the early dialogue, Hippias Minor uses the analogy of a wrestler (374a). The measure of things is good life management. Here he asks if it is the same to lead a good life as anything else we do well. Plato's Socrates replies here (apparently fictitious) that if a wrestler falls unintentionally in combat, he is a worse wrestler than one who falls intentionally. The first does not do it on purpose, but simply does not keep up straight, while the other one can use it as part of combat tactics. Ability is associated with misconduct, which is sometimes intentional in tactics. In the dialogue, Laches also talks about learning martial arts as a sport, but argues that you need to master the skill to do so. It is not just about $\tau \dot{\varepsilon} \chi v \eta$ (knowledge), but about fitness as such, which is by the sense of definition difficult to grasp.

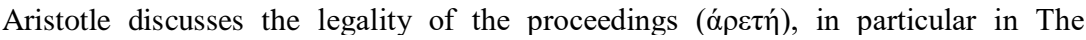
Nicomachean Ethics. The highest good is bliss, and the highest form of life is a contemplative life with a view to the truth. Aristotle speaks of harmony between the irrational and the rational part of the soul. The rational part of the soul acquires ethical as well as dianoetic virtues. Moral virtues, like crafts, are acquired thorugh practice and habituation (Nemec, Blaščíková, 2021: 52). Ethical skills arise from habit, from regularity. There is also a need for regularity in sports, where one's own fitness increases with habit. Learning about the middle (mesotes) can be applied to various sports activities, when a relatively wide range of solutions is available, but only a narrow choice of force, movement, angle, etc. is correct. Sport activity is a movement and every movement is an expression of imperfection, but it leads to a more perfect state. Some ethical virtues need powers, also necessary for sport, such as courage needs strength. As with ethical virtues, mesotes does not automatically mean the optical center.

According to Buckley (2006), Aristotle's understanding of drama in Poetics is related to sports games. The named author likens a complex drama with an Aristotelian plot

XLinguae, Volume 15 Issue 1, January 2022, ISSN 1337-8384, eISSN 2453-711X 
to the sport of cricket. Buckley asks the question: "Because sport may be seen to resemble theater, I shall ask whether sport, or some aspect of it, is a work of art "(Buckley 2006: 21). Buckley sees a structural similarity between drama and cricket. Sport, like the drama in the description in Poetics, turns individual improvised actions into a holistic entitiy of the game. Like drama, sports like cricket are mimetic in some ways. Finally, a certain part of the game can be played by the actor as a hero for the audience, which can change during the game. We believe that Buckley's analogy is not only interesting, but captures selected commonalities between drama and certain types of sports games like cricket, as described in Aristotle's Poetics. In Aristotle, art, similarly like sport, awakens moral feelings. "The perfection of art should be directly proportional to the ability to harmonize the spirit with nature" (Sucharek, 2013: 733).

In Aristotle, sport can be compared to a kind of productive craft. Holowchak argues that the Aristotelian interpretation of sport may provide some useful recommendations for today's competitive sports practice (Holowchak, 2005). Its aim is to point out what kind of sport can currently teach us something in the ethics of virtue. Although Aristotle does not directly talk about sports or athletics in Nicomachean Ethics, Holowchak sees an analogy here. According to Holowchak, the game plan has the same structure as various crafts - the military or household management. "The game plan stipulates certain perceived sub-aims that an athlete or team needs to accomplish in order to win" (Holowchak, 2005: 71).

On the other hand, Aristotle was one of the few authors who already had a critical view of sport at the time of the classical Greek period. He himself wrote in Politics: "It is no small indication that such exertions can have this impeding effect that one finds only two or three people on the list of Olympic victors who were victorious both as men and as boys, because the training of the young, and the strenuous exercises involved, robs them of their strength" (Aris. 1338b38-1139a5). On the other hand, he writes of it in the spirit of preserving the natural center as extreme excesses, that is, only when the body is beaten by excessive blows, deformed to the extent that it weakens its functionality and ability to perform other crafts. Holowchak points out that in another sense, sport is not considered worse than other crafts of its time. If sport keeps the body in a worse condition than before it was performed, then Aristotle refers to it as vulgar craft. Aristotle certainly does not reject the sport, but in Politics one can find reservations about the extremes that may accompany it. In this sense, Holowchak sees a possible ethics of Aristotle message for today's sport (Holowchak, 2005: 73). It recalls that, especially for young athletes, various excesses in physical exertion can lead to harmful effects. When some boys won in their age category, it often happened that after further advancement to the adult category, their energy was depleted prematurely, due to an effort that was excessive for their age (Politics 1388b1339a).

Here, as García Romero points out, Aristotle holds the idea that the body does not exist to be abused (García Romero, 2013: 483). In any case, Aristotle's approach to sport usability is a very suitable theoretical source. „In line of the above and under the lens of humanistic sports' contentment, we may deduce that the Aristotelian theory is dynamically existent, with an emphasis on holistic practices which endorse the development of the fullest human potential as regards to physical activity (Roumpou, 2018: 69)“. In Eudemian Ethics (1248b) Aristotle characterizes kalokagathia as such a virtue, which arises from a combination of some virtues. On this basis, Reid argues that Aristotle's idea of kalokagathia is compatible with the role of athletics in Greek poleis, but also with the civic ideal. Aristotle in this sense rejects views on innate virtues (Reid, 2020b). 


\section{Conclusion}

In European culture, within the framework of its foundations in ancient philosophy and in the social niveau, the cultural relationship of Europeans to sport was also constituted as well. At first it was the sovereign prerogative of the establishment and the rich social strata, and it continued during the Homeric period. It was because the less affluent strata did not have the resources or free time to engage in sports. They spent time working for their livelihood. Greek ayov did not mean just organized sports entertainment. The winning athletes of various types of Hellenic sports games received, in addition to considerable financial rewards, also one of the highest social awards. The athlete's successful sports personality was one of the most respected. In Athens, a turning point came with the militarization of sports activities as well as political democratization. It meant the possibility of active participation in sports outside the highest asset class. The Spartan polis allowed training for both men and unmarried women. For contemporary man, the connection between soul and body is no longer so obvious, and even much less the connection between body care and soul care. The issue was slightly outlined by the Pythagoreans, developed especially by Plato in his thoughts on the ideal state. The purpose of sport was perceived in parallel in the context of the benefit for body and soul. Despite the affirmative attitude of the absolute majority of ancient society, critical voices against athletes have occasionally appeared. Some were completely anti-mainstream. One of them was the enfante terrible of the pre-democratic philosophy of Xenophanes. He argued that sport was not socially useful.

Aristotle also expresses ambivalently. On the one hand, he is a theorist of kalokagathia in Eudemian Ethics, and he is also aware of the connection between the development of some virtues and physical fitness. On the other hand, he is very critical of the addres of engagement in sport, which puts the body in a worse state than it was before performing sports activity. He also claims that his exaggerated training at a young age can take the energy that is needed later. The foundations of general respect for job of the athlete were thus laid in ancient culture, but they did not mean only the cult of the body. For both Plato and Aristotle, this meant cultivating a certain kind of virtue. Sophists also contributed to the demand for education in physical culture. Socrates apparently left the role model of a physically unshakable, resilient man. The ideal of sport was very strong, but it did not have the character of an uncritical cult. Archaic and classical Greek philosophy reflected the company's strongly accepted social position of a successful athlete, in terms of the benefit of sport for improvement of the condition of the soul and body. It can be said that the overall position of sport was theoretically founded and strengthened within intellectual circles. Plato and Aristotle in particular contributed to this. In Plato, it was mainly a connection with his social philosophy. The historical Socrates seemed to postulate the ideal of physical steadfastness by example. Thus, the important ancient philosophers of the classical era, although to a certain extent also critically, intellectually underestimated the already established position of athletes, stretching from the Homeric period. Although its brilliance persisted throughout the Poleis, even the most famous of Sparta and Athens, archaic and classical Greek philosophy provided a mostly affirmative theoretical reflection that included a periodistic dualistic psychophysical view of man.

\section{Acknowledgments}

The authors would like to acknowledge the support of Prince Sultan University for paying the Article Processing Charges (APC) of this publication.

XLinguae, Volume 15 Issue 1, January 2022, ISSN 1337-8384, eISSN 2453-711X 
The article was supported by an international grant Philosophical and ethical aspects of sport NP-KSV-ET-01-2021-12/SP.

\section{Bibliographic references}

Appelboom, T., Rouffin, C. and E. Fierens (1988). "Sport and medicine in ancient Greece" The American Journal of Sports Medicine 16(6), 594-596

Buckley, A. D. (2006). "Aristotle and Cricket: Drama in Retrospect" Journal of the Philosophy of Sport 33(1), 21-36

Carr, D. (2010). "On the moral value of physical activity: Body and soul in Plato's account of virtue" Sport, Ethics and Philosophy 4(1), 3-15

Corlett, J. (1996). "Sophistry, Socrates and Sport Psychology" Sport Psychologist 10(1), 84-94

Daquing, W. (2010). "On the Ancient Greek $\alpha \gamma \omega v$ " Procedia - Social and Behavioral Sciences 2(5), 6805-6812

Dombrowski, D. A. (2012). "Homer, competition and sport" Journal of the Philosophy of Sport 39(1), 33-51

Dombrowski, D. A. (2015). "Homer and competitive play" in M. MacLean et al (eds). Philosophical Perspectives of Play. Abingdon: Taylor and Francis Inc., 107-119

Dombrowski, D. A. (1979). "Plato and athletics" Journal of the Philosophy of Sport 6(1), 29-38

Garcia Romero, F. (2013). "Sports practice and body's limits in the Corpus Hippocraticum, Plato and Aristotle" Medicina nei secoli 25(2), 473-490

Heckel, M. (2017). „Plato on the role of contradiction and education” British Journal for the History of Philosophy 25(1), 3-21

Holowchak, M. A. (2005). "Virtue, Craft and Contest: An Aristotelian Approach to Competitive Sport" Sport in Society 8(1), 65-75

Hunnicutt, B. K. (1990). "Leisure and play in Plato's teaching and philosophy of learning” Leisure Sciences: An Interdisciplinary Journal 12(2), 211-227

Christesen, P. (2017). "Sparta and athletics" in Powell, A. (ed.) A companion to Sparta 1. Chichester: Classical Press Wiley - Blackwell, 544-564

Christesen, P. (2012). "Athletics and Social Order in Sparta" Classical Antiquity 31(2), 193-255

Jenkins, M. (2015). "Early Education in Plato's Republic" British Journal for the History of Philosophy 23(5), 843-863

Kaplan, E. H. and C. Rich (2017). "Decomposing Pythagoras” Journal of Quantitative Analysis in Sport 13(4), 141-149

Konsolaki, E., Astyrakaki, E., Stefanakis, G., Agouridakis, P., Askitopoulou, H. (2010). "Cranial trauma in ancient Greece: From Homer to classical authors" Journal of Cranio-Maxillofacial Surgery 38(8), 549-555

Markovich, M. (1978). "Xenophanes on Drinking Parties and Olympic Games" Ilinnois Classical Studies 3, 1-26

Milne, J. G. (1943). The chronology of Solon reforms. The Classical Review 57(1), 13

Nemec, R. and A. Blašč́ková (2021). "Two perspectives on the issue of prudence (prudentia): Thomas Aquinas and William of Ockham" Konštantínove listy 14(2), 5160

Oborný, J. (2011). Corporality, sport and erotica. Human Movement 12(2), 203-207

Pritchard, D. M. (2016). Sport and Democracy in Classical Athens. Antichthon 50, 50-69

Pritchard, D. M. (2012). Public honours for panhellenic sporting victors in democratic Athens. Nikephoros 25, 209-220

Reid, H. (2020a). Heroic Parthenoi and the Virtues of Independence: A Feminine Philosophical Perspective on the Origins of Women's Sport. Sport, Ethics and Philosophy 14, 511-524 
Reid, H. (2020b). Athletic virtue and aesthetic values in Aristotle's ethics. Journal of the Philosophy of Sport 47(1) 63-74

Reid, H. (2017). Sport and moral education in Plato's Republic. Journal of the Philosophy of Sport 34(2), 160-175

Reid, H. (2012). Athletic beauty in classical greece: A philosophical view. Journal of the Philosophy of Sport 39(2), 281-297

Roumpou, S. (2018). Aristotle's entelechy and eudaimonia in sports. Psychological Thought 11(2), 62-74

Scala, A. (2016). Sport and philosophy. Filozofia 71(7), 541-549

Scanlon, T. F. (2018). Class tensions in the games of Homer: Epeius, Euryalus, Odysseus and Iros. Bulletin of the Institute of Classical Studies 61(1), 5-20

Scanlon, T. F. (2005). The dispersion of pederasty and the athletic revolution in sixth century BC Greece. Journal of Homosexuality 49(3-4), 63-85

Sucharek, P. (2013). An artist: Pontifex oppositorum. Filozofia 68(9), 845-859

Suvák, V. (2014). Socratic therapeia: The Role of Socrates. Filozofia 69(10), 824-834

Stolyarov, V. I. (2017). The development of the philosophy of sport and the Russian philosophical school humanistic and dialectical analysis of sport. Voprosy Filosofii 8, 202-214

Thompson, K. (2002). Socrates, sport and students: A philosophical inquiry into physical education and sport. Journal of the Philosophy of Sport 29(2), 190-192

Van Nispen, H. (2020). "A Woven Web of Guesses: Xenophanes of Colophon" Apeiron 51(4), 391-403

Wollner, U. (2010). The problem of self-knowledge in Xenophon's Memorabilia Filozofia 6(7), 622-630

Wyskok, M. and M. Bronikowska (2018). Sport and politics in Archaic Greece International Journal of the History of Sport 35(14), 1476-1489

Zhmud, L. (2012). Pythagoras and Early Pythagoreans. Oxford: OUP

Zuchora, K. (1983). Agon as the Way of Life (or back to „The Iliad“ and „The Odyssey“). International Review for the Sociology of Sport 18(4) 7-35

Words: 5788

Characters: 36587 (20,33 standard pages)

Mgr. et Mgr. Peter Šagát, PhD Assistant professor

Prince Sultan University Riyadh

Saudi Arabia

sagat@seznam.cz

Assoc. prof. PhDr. Marián Ambrozy, PhD., MBA (corresponding author)

College of International Business ISM Slovakia in Presov

Duchnovičovo námestie 1

Prešov 08001

Slovakia

ambrozy@imspo.sk

XLinguae, Volume 15 Issue 1, January 2022, ISSN 1337-8384, eISSN 2453-711X 